A N N A LE S

UNIVERSITATIS MARIAE CURIE-SKŁODOWSKA

LUBLIN - POLONIA

VOL. XXXIV

SECTIO FF

$2-2016$

\title{
KAROLINA WIELICZKO-PALUCH
}

Uniwersytet Marii Curie-Skłodowskiej

\section{Postapokalipsa, baśń i groza w Pikniku na skraju drogi braci Strugackich}

The post-apocalypse, fairy tales and horror in Roadside Picnic by the Strugatsky brothers

Piknik na skraju drogi (1972) jest jednym z utworów braci Arkadija i Borysa Strugackich, w których podjęto tematykę postapokaliptyczną, wpisując ją w schemat powieści o kontakcie ziemskiej cywilizacji z Obcymi w bliskiej przyszłości (podobny zamysł realizują Drugi najazd Marsjan i Las tych samych autorów). Piknik zestawia się niekiedy z Solaris Stanisława Lema, dostrzegając, iż kluczowym problemem poruszanym przez autorów w obu przypadkach jest kwestia „nieprzystawalności poznawczej”. W przypadku dzieła polskiego pisarza bazą dla problematyki epistemologicznej jest jednoczesna konieczność i zarazem niemożność przekroczenia granic poznania wyznaczanych przez antropocentryzm. O ile jednak w Solaris postać Obcego została czytelnikowi ukazana w ograniczonej mierze (doszło do zetknięcia - próby kontaktu między istotami niewyobrażalnie różnymi), o tyle w utworze Strugackich przybysze zachowują całkowitą anonimowość. Nie zostały podane żadne dane, które mogłyby posłużyć jakiejkolwiek ich charakterystyce, więc czytelnik jedynie przypuszcza, jacy są. Bez odpowiedzi pozostają najistotniejsze pytania, jak chociażby o to, skąd „Oni” przybyli i czy mają fizyczną formę, co szczególnie ważne - nieznane pozostają

${ }^{1}$ J. Sobota, Konfrontacja wartości moralnych Obcych i ludzi w literaturze science fiction, [w:] idem, Konflikty moralne. Literatura fantastycznonaukowa jako próba symulacji sytuacji konfliktowych, Olsztyn 2011, s. 199. W pewien sposób obie powieści zestawia także S. Żiżek, idem, Andriej Tarkowski albo Rzecz z przestrzeni psychicznej, przeł. J. Kutyła, [w:] idem, Lacrimae rerum. Kieślowski, Hitchcock, Tarkowski, Lynch, przeł. G. Jankowicz, J. Kutyła et al., Warszawa 2011, s. 210-224. 
także ich intencje. Właściwie nie wiadomo do końca, czy kosmici w ogóle dotarli na Ziemię, a jeśli tak - to czy ją opuścili. Za źródło wiedzy o gościach z Kosmosu mogłyby jedynie posłużyć wytwory ich cywilizacji, rozrzucone w tak zwanych Strefach, które (zgodnie z sugerowaną w tytule koncepcją, nieakceptowaną przez wszystkich krytyków ${ }^{2}$ ) stanowią rodzaj śmietniska, pozostawionego po ich - raczej przypadkowej - styczności z naszą planetą. Terytorium naznaczone śladami wizyty nieznajomych stanowi sześć zamkniętych obszarów. Za sprawą przyjętej przez autorów strategii wycinkowego prezentowania świata przedstawionego oglądamy oczami bohaterów tylko jedną ze Stref, znajdującą się w mieście Harmont. Pełniący funkcję ekspozycji wywiad z noblistą doktorem Walentinem Pillmanem, a także kolejne cztery rozdziały powieści pozwalają czytelnikowi pobieżnie zapoznać się z ośmioletnią historią miasteczka, na którą złowrogim cieniem padł incydent określany mianem „Lądowania”.

Należy wyjaśnić, iż „katastrofa w wypadku postapokalipsy ma charakter totalny - albo dotyczy całej planety, zmieniając oblicze Ziemi, albo doprowadza do trwałej destrukcji i transformacji jakiegoś obszaru, na zawsze straconego dla normalnego życia"3. Tak jest w powieściowej Strefie bądź zonie w opartym na motywach książki Strugackich filmie Andrieja Tarkowskiego ${ }^{4}$. Następstwa katastrofy, jaką bezsprzecznie było Lądowanie, dotknęły w wymierny sposób znaczną części ludzkości. Najbardziej wstrząsające konsekwencje wiązały się z całkowitą zagładą ziemskich form życia biologicznego w obszarze Strefy. Mieszkańcy skażonych terenów zapadali na niezidentyfikowane, najczęściej śmiertelne choroby. Bezpośrednie skutki Lądowania uczyniły ze Strefy rodzaj obszaru eksterytorialnego, do którego wstęp stał się dla Ziemian niezwykle niebezpieczny. Ów kosmiczny zakazany owoc skusił jednak przedstawicieli rozmaitych organizacji i gałęzi przemysłu, a także zwykłych ludzi, którzy przybywali do Harmont dla zysku lub z ciekawości. To doprowadziło do paradoksalnego rozwoju ekonomicznego i demograficznego miasteczka, tym samym przekształcając je w ośrodek militarno-naukowo-turystyczno-rozrywkowy. Inne negatywne skutki katastrofy objawiły się pełniej w późniejszym okresie, kiedy doszło do eskalacji szkodliwych oddziaływań Strefy w skali globalnej - okazało się, iż w miejscach osiedlania się emigrantów z Harmont następował wzrost przypadków śmiertelności lokalnej populacji. Śmierć zbierała żniwo niczym klątwa tajemniczego bóstwa.

${ }^{2}$ Confer: S. Lem, Postowie, [w:] A. i B. Strugaccy, Piknik na skraju drogi. Las, przeł. I. Lewandowska, Kraków 1977, s. 277-288 (w powyższym wydaniu znalazły się więc utwory, które łączy koncept zagrażającej pewnej społeczności przestrzeni, wypełnionej niezrozumiałymi, destrukcyjnymi zjawiskami oraz przedmiotami).

${ }^{3}$ L. M. Nijakowski, Popularne postapokalipsy późnej nowoczesności, [w:] Mit, prawda, imaginacja, red. P. L. Kowalski, Wrocław 2011, s. 248-249.

${ }^{4}$ Stalker, reż. A. Tarkowski, ZSRR 1979. 
Autorzy wprowadzili w świat Harmont symptomatyczne dla czasów apokalipsy postacie wskrzeszonych zmarłych (nasuwa się kontekst biblijny - Ap 20). Szkielety powstałych z grobów mieszkańców miasteczka okrywała tkanka pozornie podobna do ludzkiej, lecz wykazująca dość makabryczną właściwość „autonomicznej zdolności do życia"5 (co przywodzi na myśl pomysły surrealistów). Widmowi zmarli powracali do swych dawnych siedzib, usiłując zająć znów miejsce wśród domowników i towarzyszyć im w codziennej egzystencji. Opisy zmartwychwstańców wprowadzają atmosferę niesamowitości, tak charakterystyczną dla fantastyki grozy ${ }^{6}$ :

Nunnun przeszedł kilka kroków korytarzem i zatrzymał się przed drzwiami jadalni. Stary siedział przy stole. Sam. Fantom. Nieruchomy i odrobinę przekrzywiony na bok. Różowe światło abażuru padało na jego szeroką ciemną twarz jakby wyrzeźbioną w starym drzewie, na zapadnięte, bezzębne usta, na oczy martwe i bez połysku. I Nunnun natychmiast poczuł ten zapach. Wiedział, że to tylko gra wyobraźni, zapach był tylko przez pierwsze dni, a potem doszczętnie znikał, ale Richard Nunnun czuł go jakby pamięcią - duszny, ciężki zapach rozkopanej ziemi .

Do utworów science fiction zostają wprowadzone elementy grozy wówczas, gdy ,głównym celem autora jest ukazanie skutków niezwykłego wydarzenia czy zjawiska, zaś samo zjawisko, jego wytłumaczenie i uzasadnienie staje się sprawą drugorzędną" go w powieści Strugackich można rozpoznać wskazane przez Rogera Caillois tematy realizowane w obrębie „fantastyki przerażenia”. Pochodzące z kosmosu przedmioty i zjawiska, znajdujące się w Strefie, stanowią różne warianty opisanej w szkicu krytyka tajemniczej „,rzeczy” - ,nie dająca się określić i niewidzialna [...] ciąży, jest obecna, zabija albo szkodzi" ${ }^{10}$. Pojawienie się powracających do swoich domów zmarłych mieszkańców Harmont można uważać za ciekawą kontaminację dwóch typów postaci: zarówno nieumarłego zombie, jak i posągów, manekinów czy automatów, „które nagle ożywają i stają się groźnie niezależne”11. Natomiast kolejny element świata fantastyki grozy - przekleństwo - przybiera formę złowrogiej i nieuleczalnej choroby. W Pikniku na skraju drogi pojawia się ciekawy wariant tego motywu.

${ }^{5}$ A. Strugacki, B. Strugacki, Piknik na skraju drogi, przeł. I. Lewandowska, Warszawa 1974, s. 179.

${ }^{6} \mathrm{~W}$ znaczeniu odnotowanym przez A. Niewiadowskiego i A. Smuszkiewicza. Leksykon polskiej literatury fantastycznonaukowej, red. B. Kledzik, Poznań 1990, s. 316-317.

${ }^{7}$ A. Strugacki, B. Strugacki, op. cit., s. 183.

${ }^{8}$ B. Okólska, SF, fantastyka, baśń, [w:] Spór o SF. Antologia szkiców i esejów o science fiction, wybór R. Handke, L. Jęczmyk, B. Okólska, Poznań 1989, s. 210.

${ }^{9}$ R. Caillois, Od baśni do science fiction, przeł. J. Lisowski, [w:] idem, Odpowiedzialność i styl. Eseje, przeł. J. Błoński, Warszawa 1967, s. 47-48.

${ }^{10}$ Ibidem, s. 47.

${ }^{11}$ Ibidem, s, 48. 
Red Shoehart, protagonista powieści jest stalkerem - przedstawicielem profesji nierozerwalnie związanej z istnieniem Strefy. Stalkerzy przekraczali jej granicę po prostu dla zarobku i tym samym byli łącznikami między Strefą a resztą świata. Poza ryzykiem związanym z łamaniem lokalnego prawa stalkerzy narażali się także na innego rodzaju konsekwencje. Ceną za zachowanie przez ryzykantów tak upragnionej - jak nazywał to Red - „niezależności finansowej”, uzyskiwanej ze sprzedaży przedmiotów ze Strefy, okazała się nieznana mutacja, której zostało poddane potomstwo niektórych z nich. Ukazuje to przypadek Mariszki, córki Reda, która stopniowo zatraca fizyczne i umysłowe cechy ludzkie, upodabniając się do zwierzęcia. Ponadto wydaje się, że ciało Reda także zyskało pewną nadzwyczajną właściwość - nadludzką siłę, która pozwoliła mu wyrzucić z mieszkania nieproszonych gości. Co zaskakujące, mutacja jednak nie dotknęła wszystkich często wędrujących do Strefy. Inny stalker, Ścierwnik Barbridge, doczekał się dwojga zdrowych i urodziwych dzieci. Jak wyznał Redowi, sekret owej pomyślności tkwił w mocy jeszcze jednego, owianego legendą artefaktu ze Strefy. W ten sposób dowiadujemy się o istnieniu Złotej Kuli mającej moc spełniania życzeń i słusznie możemy spodziewać się, iż zgodnie ze schematem baśniowym bohater podejmie się jej odnalezienia.

Nawiasem mówiąc, baśniowy schemat został uaktualniony w fabule o wiele wcześniej. Motyw zmian dokonujących się w Mariszce to wyraźny przykład baśniowości, drugim jest epizod wyprawy po cudowny przedmiot, ekwiwalent złotego runa, ukrytego skarbu czy kwiatu paproci, który pojawił się już w pierwszym rozdziale powieści, zawierającym relację z ekspedycji naukowej oraz opisującym jej skutki. Realizacja celu misji, czyli odnalezienie pułapki magnetycznej, została okupiona życiem naukowca Kiryła Panowa, towarzyszącego Redowi w Strefie. Omawiany rozdział antycypuje ostatnią wyprawę bohatera, podczas której ginie młody chłopak Artur, który reprezentuje ten sam typ postaci, co Kirył. Obaj są jednostkami wartościowymi społecznie i idealistycznie pojmującymi świat.

Złotą Kulę, mimo genetycznej przynależności do gatunku baśni, można zaklasyfikować jako jeden z samodzielnych rekwizytów, który mieści się również $\mathrm{w}$ konwencji science fiction ${ }^{12}$. Tajemniczy artefakt, nazywany w powieści także „maszyną życzeń”, pojawia się w utworze niczym milczące bóstwo - akcja utworu urywa się tuż przed oczekiwaną demonstracją jego działania. Opis urządzenia oglądanego oczami Reda jest dość lakoniczny („Nie była złota, była raczej miedziana, czerwonawa, idealnie gładka, matowo połyskująca w słońcu"13), zatem warto skupić się na konotacjach jego nazwy, takich jak: boskość, doskonałość i pełnia, potęga i bogactwo, które czynią Złotą Kulę przedmiotem pożądania ludzi, zapominających na razie o tym, że może być ona także rodzajem konia

${ }^{12}$ A. Smuszkiewicz, Stownik fabularny i chronografia, [w:] idem, Stereotyp fabularny fantastyki naukowej, Wrocław 1980, s. 141.

${ }^{13}$ A. Strugacki, B. Strugacki, op. cit., s. 233. 
trojańskiego pozostawionego przez obcą cywilizację. Kształt cudownej maszyny odpowiada na poły ironicznym rozważaniom Rolanda Barthes'a na temat Latających Spodków:

W przyszłości psychoanalitycy będą mogli wyjaśnić figuratywne elementy owej mocy, składające się na nią tematy oniryczne: krągłość pojazdu, gładkość jego metalu, ten szczyt możliwych osiągnięć, jakim byłaby materia bez szwów; wszystko to a contrario pozwala nam lepiej zrozumieć to, co w polu naszej percepcji łączy się z motywem Zła: załamania, nieregularne płaszczyzny, szum, nieciągłość powierzchni ${ }^{14}$.

Ponadto postaci Artura, młodego syna Barbridge'a, symbolicznie patronuje wielki imiennik z celtyckich legend. Wszak to rycerze arturiańscy poszukiwali Świętego Graala. Artur do końca pozostał niewinny i czysty w swych intencjach - aż chciałoby się zapytać, czy ludzkość nie zyskałaby więcej, gdyby ofiarą ,wyżymaczki” został sam siebie nazywający „łajdakiem” i „oprychem” Red? Wprawdzie Shoehart, choć zdawał się mieć własne pragnienia, ostatecznie nie potrafił ich wyartykułować, zatem pozostało mu tylko powtórzyć altruistyczny postulat Artura: „szczęście dla wszystkich za darmo”. Wypada uznać za wątpliwe, czy został on w ogóle zrealizowany, gdyż, zgodnie ze słowami Reda: „Złota Kula spełnia tylko najskrytsze życzenia, tylko takie, które muszą się spełnić, bo inaczej nie ma już po co żyć!" 15 . Najbardziej szlachetne pragnienie stalkera dotyczyło wprawdzie uleczenia córki, jednak treść wewnętrznego monologu bohatera, poprzedzającego dotarcie do Kuli, doskonale mieści się w dwóch wygłoszonych przez niego zdaniach: „Kamień na kamieniu z tego nie zostanie. Teraz ja o wszystkim decyduję"16 - wyrażających poczucie osobistej krzywdy i chęć zemsty na ludzkości. W pewnym sensie Red jest antybohaterem, jednak to nade wszystko postać dwuznaczna, wręcz tragiczna. Oszukiwany przez zleceniodawców i fałszywego przyjaciela, złamany pobytem w więzieniu, nieszczęśliwy z powodu choroby Mariszki - wędrując ku Złotej Kuli, odbywa swego rodzaju psychomachię. Uwewnętrznienie formuły o „szczęściu dla wszystkich za darmo” czyni z Reda reprezentanta ludzkości, wystawionego na próbę i ostatecznie wychodzącego z niej zwycięsko moralnie. Strefa w powieści staje się odpowiednikiem specyficznej pokusy. Kosmiczne artefakty, może poza wyraźnie oddzieloną od pozostałych Złotą Kulą, uważa się w powieści za „diabelskie” wcale nie dlatego, że są groźne i nieprzewidywalne w swym wpływie na zdrowie czy życie człowieka, ale z powodu tego, na co można je wymienić poza Strefą. Doskonale rozumiał to dziwak Szuwaks, przyjaciel Reda, który skupował towary wyniesione z zony i pod osłoną nocy zakopywał je tam z powrotem, oddając, jak powia-

${ }^{14}$ R. Barthes, Marsjanie, [w:] idem, Mitologie, przeł. A. Dziadek, wstęp K. Kłosiński, Warszawa 2008, s. 63.

${ }^{15}$ A. Strugacki, B. Strugacki, op. cit., s. 207.

${ }^{16}$ Ibidem, s. 226. 
dał, „co szatańskie - szatanowi” ${ }^{17}$. Świat ludzki ukazany w powieści jeszcze przed Lądowaniem był zdeprawowany przez materializm i intensywne użytkowanie. Przypomina się w tym miejscu innego rodzaju „baśń”, anegdota przytoczona przez Jeana Baudrillarda dla objaśnienia mechanizmów konsumpcji. Red Shoehart, nielubiący „liczyć każdego grosza” i pragnący kupić „fajny cottage” to w gruncie rzeczy Baudrillardowski „człowiek «obdarzony» potrzebami, które «skłaniają» go ku przedmiotom «zapewniającym» mu zadowolenie [...] ta sama historia musi rozpoczynać się od nowa w nieskończoność, z jałową samooczywistością właściwą wszelkim starym baśniom" ${ }^{\prime 18}$.

Ostatecznie w Redzie zwycięża faustowska wizja sprawiedliwej i nasyconej ludzkości. Podobnie jak w dramacie Goethego marzenie to okaże się utopią ślepca, zaś szlachetny - być może - zamiar zostanie okupiony okrutnym mordem niewinnego. Fredric Jameson nazwał powieść Strugackich ,jedną z najwspanialszych współczesnych utopii" ${ }^{19}$, która stanowi zrozumiałe uzupełnienie apokaliptycznego tematu, ,ponieważ oryginalna Apokalipsa zawiera zarówno katastrofę, jak i dopełnienie dziejów, [...] utopię i wygaśnięcie rasy ludzkiej”20. Możliwie najbardziej optymistyczna wymowa powieści opierałaby się zatem na samym fakcie zaistnienia ,jasnego punktu” w powieściowej narracji, znalezienia dla obrazu powszechnej i dozgonnej szczęśliwości miejsca w dość pesymistycznym świecie Pikniku na skraju drogi.

Wprowadzenie do powieści tymczasowej wizji utopijnej naturalnie nie znajduje wystarczającego uzasadnienia w prostym przeciwstawieniu konsumpcjonizmowi społeczeństwa kapitalistycznego - ideologii socjalistycznej ${ }^{21}$, której skutków autorzy doświadczali każdego dnia. Interpretacja utworu powinna osadzać się na rozpoznawaniu procesów przemian społeczeństwa nowoczesnego ponad powyższym podziałem. Odwołując się do wspomnianego w tym tekście dzieła Lema, warto zaznaczyć, że to właśnie on jako pierwszy zauważył, iż mimo poniesienia dość znacznych kosztów odwiedzin mieszkańców Kosmosu (liczonych ilością ofiar złożonych z życia zwykłych obywateli), a nawet mimo koniecznych przewartościowań w dziedzinie nauki i filozofii, ludzkość potrafiła „zagospodarować" złowrogie obszary Nieznanego, dążąc do maksymalizacji płynących ze Strefy korzyści - przede wszystkim finansowych, militarnych i naukowych. Przyjęcie stanowiska niewykształconego bohatera, obracającego się w półświat-

${ }^{17}$ Ibidem, s. 63.

${ }_{18}$ J. Baudrillard, Sekcja homo oeconomicus, [w:] idem, Społeczeństwo konsumpcyjne, przeł. S. Królak, Warszawa 2006, s. 76.

${ }^{19}$ F. Jameson, Archeologie przyszłości. Pragnienie zwane utopia i inne fantazje naukowe, przeł. M. Płaza, M. Frankiewicz, A. Miszk, Kraków 2011, s. 348.

${ }^{20}$ Ibidem, s. 236-237.

${ }^{21}$ Hipoteza ta zdominowała interpretacyjne wysiłki krytyków powieści w ZSRR (confer: W. Kajtoch, Bracia Strugaccy (zarys twórczości), Kraków 1993, s. 142-143. 
ku, zezwoliło na ominięcie szerszej perspektywy, mogącej dać pojęcie na temat zmian politycznych i kulturowych na Ziemi, które musiały nastąpić po wizycie Obcych. Zamiast tego obraz ukazanego w powieści postapokaliptycznego świata koncentruje się na owej mrówczej zapobiegliwości i obrotności „konsumentów” Strefy. Lem zastanawiał się nad trafnością oryginalnej wizji społecznych (politycznych, ideologicznych) konsekwencji Lądowania, w zasadzie nijakich w stosunku do skali przełomu. Odwołując się do słów doktora Pillmana o „zbyt stacjonarnym układzie”22, wyjaśniał: „kontakt z Innym nie może, jeśli nie równa się globalnej katastrofie, odmienić gwałtownie ruchu dziejów ludzkich, ponieważ ludzkość nie jest w stanie nagle «wyskoczyć» ze swojej historii i wejść [...] w całkowicie odmienną"23.

Co interesujące, tego rodzaju model stacjonarny czy „immobilistyczny” znajduje miejsce w pewnych typologiach ujęć czasu historycznego ${ }^{24}$. W jego obrębie używane w dyskursie historycznym pojęcie „przełomu historycznego" traci sens, co zauważył Wojciech Kajtoch ${ }^{25}$. Ów przełom nie jest możliwy w świecie zaprojektowanym przez Strugackich, ponieważ bracia udowadniają, że konieczna do jego wystąpienia jest zmiana struktury świadomości ludzkiej, zaś katastrofizm powieści polega na unaocznieniu beznadziei oczekiwania na taką przemianę. Nie znamy szczegółów inwazji, nie wiemy nic o jej przyczynach, ani o winnych, bo nie to leży w centrum zainteresowania twórców Pikniku. Lądowanie jako fakt sam w sobie nie wydaje się tak naprawdę interesujące, gdy istnieje perspektywa dowiedzenia się czegoś o nas samych ${ }^{26}$. Autorzy sugerują, iż tylko pozornie mamy do czynienia z Lądowaniem jako ingerencją czynnika zewnętrznego. W rzeczywistości stanowi ono maskę dla wszelkich perturbacji dziejowych, jakie znamy z lekcji historii. $Z$ tej baśni wynikałaby zatem nauka o tym, że skoro tak szybko zaadaptowaliśmy tak niezrozumiałe i szokujące wydarzenie, jakim był kontakt z obcą i o wiele potężniejszą cywilizacją - bez większych trudności poradzimy sobie już ze wszystkim. Niniejszej konstatacji przyświecają dwie myśli. Pierwsza z nich opiera się na zaczerpniętej od Platona tezie, iż podłoże życia politycznego i procesów historycznych ma charakter ekonomiczny ${ }^{27}$. Druga natomiast stanowi wyraz niezależności twórczej Strugackich od ideologicznych uwikłań czasu, w którym powieść powstawała, wynosząc utwór do rangi metafory in-

${ }^{22}$ A. Strugacki, B. Strugacki, op. cit., s. 162.

${ }^{23}$ S. Lem, op. cit., s. 276.

${ }^{24}$ Model ten jest jednym z sześciu uwzględnionych przez C. S. Bartosiaka, opisany zostały za pomocą metafory pustyni, w której „,wiatr przesypuje trochę piasku z miejsca na miejsce”. Idem, Historia ludzka i Chrystus, Katowice 1987, s. 13.

${ }^{25}$ Confer: W. Kajtoch, op. cit., s. 144.

${ }^{26}$ Confer: L. Bugajski, ,,Przenicowany świat”, [w:] idem, Spotkania drugiego stopnia, Kraków 1983, s. 107.

${ }^{27}$ Confer: K. Popper, Zmiana i bezruch, [w:] idem, Spoleczeństwo otwarte i jego wrogowie, t. 1, Urok Platona, przeł. H. Krahelska, oprac. A. Chmielewski, Warszawa 1993, s. 60-61. 
dywidualnego losu ludzkiego, pojmowanego w kategoriach bliskich egzystencjalizmowi. Red Shoehart, tuż przed wypowiedzeniem życzenia, dziwiąc się: „przecież to niemożliwe, żebym chciał zła!”28, wybiera w imię całej ludzkości, odrzucając własny egoizm. Jean-Paul Sartre rzekłby, że dokonanie czynu - wyboru na korzyść bliźnich - można uznać za równoznaczne ze wzbudzeniem w sobie dobrych uczuć dla ludzkości. Baśniowa wymowa finału wraz z wprowadzonym elementem nadprzyrodzonym podważają specyficzny dla science fiction związek świata przedstawionego z empiryczną rzeczywistością, sugerując, że rzeczywistości projektowanej przez Reda w jego życzeniu trudno przypisać ten stopień wiarygodności, co pozostałym składowym fabuły. To, co w powieści bezwarunkowo dobre - ginie lub można „między bajki włożyć”, zaś z piekła ludzkiego życia na Ziemi może nie być ratunku. Stąd wypływa właściwe źródło lęku towarzyszącego lekturze Pikniku na skraju drogi:

Wczorajsza rewolucja dała początek fantastyce. Z dzisiejszej - zrodziła się science fiction, w części mieszanina apoteozy i apokalipsy, a mówiąc skromniej - nowy obraz człowieka jako istoty przypadkowej, żyjącej na uboczu i przemijającej, zagubionej w przerażającym bezmiarze wszechświata ${ }^{29}$.

\section{BIBLIOGRAFIA}

Barthes R., Marsjanie, [w:] idem, Mitologie, przeł. A. Dziadek, wstęp K. Kłosiński, Warszawa 2008, s. $63-65$.

Bartosiak C. S., Podstawowe problemy historii, [w:] idem, Historia ludzka i Chrystus, Katowice 1987, s. 7-17.

Baudrillard J., Sekcja homo oeconomicus, [w:] idem, Społeczeństwo konsumpcyjne, przeł. S. Królak, Warszawa 2006, s. 75-86.

Bugajski L., „Przenicowany świat”, [w:] idem, Spotkania drugiego stopnia, Kraków 1983, s. 107-117.

Caillois R., Od baśni do science fiction, przeł. J. Lisowski, [w:] idem, Odpowiedzialność i styl. Eseje, przeł. J. Błoński et at., Warszawa 1967, s. 29-65.

Caillois R., Science fiction, przeł. B. Okólska, [w:] Spór o SF. Antologia szkiców i esejów o science fiction, wybór R. Handke, L. Jęczmyk, B. Okólska, Poznań 1989, s. 179-200.

Jameson F., Archeologie przyszłości. Pragnienie zwane utopia i inne fantazje naukowe, przeł. M. Płaza, M. Frankiewicz, A. Miszk, Kraków 2011.

Kajtoch W., Bracia Strugaccy (zarys twórczości), Kraków 1993.

Lem S., Posłowie, [w:] A. i B. Strugaccy, Piknik na skraju drogi. Las, przeł. I. Lewandowska, Kraków 1977, s. 265-288.

Niewiadowski A., Smuszkiewicz A., Leksykon polskiej literatury fantastycznonaukowej, red. B. Kledzik, Poznań 1990.

Nijakowski L. M., Popularne postapokalipsy późnej nowoczesności, [w:] Mit, prawda, imaginacja, red. P. L. Kowalski, Wrocław 2011, s. 243-269.

${ }^{28}$ A. Strugacki, B. Strugacki, op. cit., s. 239.

${ }^{29}$ R. Caillois, Science fiction, [w:] Spór o SF, s. 195. 
Okólska B., SF, fantastyka, baśń, [w:] Spór o SF. Antologia szkiców i esejów o science fiction, wybór R. Handke, L. Jęczmyk, B. Okólska, Poznań 1989, s. 201-212.

Popper K., Zmiana i bezruch, [w:] idem, Społeczeństwo otwarte i jego wrogowie, t. 1, Urok Platona, przeł. H. Krahelska, oprac. A. Chmielewski, Warszawa 1993, s. 57-78.

Smuszkiewicz A., Stownik fabularny i chronografia, [w:] idem, Stereotyp fabularny fantastyki naukowej, Wrocław 1980, s. 141-143.

Sobota J., Konfrontacja wartości moralnych Obcych i ludzi w literaturze science fiction, [w:] idem, Konflikty moralne. Literatura fantastycznonaukowa jako próba symulacji sytuacji konfliktowych, Olsztyn 2011, s. 183-208.

Stalker, reż. A. Tarkowski, ZSRR 1979.

Strugacki A, Strugacki B., Piknik na skraju drogi, przeł. I. Lewandowska, Warszawa 1974.

Żiżek S., Andriej Tarkowski albo Rzecz z przestrzeni psychicznej, przeł. J. Kutyła, [w:] idem, Lacrimae rerum. Kieślowski, Hitchcock, Tarkowski, Lynch, przeł. G. Jankowicz, J. Kutyła et al., Warszawa 2011, s. 199-239.

\section{STRESZCZENIE}

Artykuł został poświęcony Piknikowi na skraju drogi Arkadija i Borysa Strugackich - wizji postapokaliptycznego świata po wydarzeniu zwanym Lądowaniem. Pierwsza część tekstu dotyczy krótkiego porównania dwóch powieści science fiction, w których poruszono temat nieudanej próby kontaktu pomiędzy ludźmi i istotami pozaziemskimi. Następnie opisano postapokaliptyczne miasto ze znajdującą się w nim Strefą oraz zinterpretowano niektóre motywy zaczerpnięte z fantastyki grozy. W dalszej części szkicu przedstawiono protagonistę oraz jeden z artefaktów znajdujących się w Strefie, reprezentujących pewien typ postaci i rekwizytów znanych z baśni, legend oraz mitów. Kolejna część tekstu koncentruje się wokół motywu utopijnego, pojawiającego się w finale powieści i jednocześnie stanowiącego ilustrację przemiany głównego bohatera, ujętej na tle filozofii egzystencjalizmu. Analizy prowadzą do wniosku, iż Piknik na skraju drogi stanowi wyraz krytycznego stosunku Strugackich do nowoczesnego społeczeństwa konsumpcyjnego.

Słowa klucze: Arkadij i Borys Strugaccy, Piknik na skraju drogi, istoty pozaziemskie, stalker, Strefa, postapokalipsa, motywy i rekwizyty baśniowe, baśń, groza, Faust, przełom historyczny, utopia, konsumpcjonizm, egzystencjalizm J.-P. Sartre'a

\section{SUMMARY}

The article is devoted to Roadside Picnic by Arkady and Boris Strugatsky - a post-apocalyptic vision of the world after an extraterrestrial event called Visitation. The first part deals with a short comparison of two science fiction novels about the failed contact between humans and aliens. The second part of this paper describes a post-apocalyptic town with a Visitation Zone and interprets some motifs from fantastic horrors. The third part presents a protagonist and one of the artefacts in the Zone representing a type of a character and an item known from fairy tales, legends and myths. The next part focuses on a utopian motif in the final part of the novel, which illustrate protagonist's transformation on the background of existentialism. The analysis leads to the conclusion that the Strugatsky's Roadside Picnic contains the disapprobation of the modern consumerist society.

Keywords: Arkady and Boris Strugatsky, Roadside Picnic, extraterrestrials, stalker, the Zone, post-apocalypse, motifs and items in fairy-tales, horror, fairy-tale, Faust, historical watershed, utopia, consumerism, existentialism of J.-P. Sartre 